\title{
Exemplary Amateurism
}

Thoughts on DIY Urbanism

\section{ANN DESLANDES}

A blog entry by the futurist Bruce Sterling for the US technology magazine Wired, dated 12 July 2009, profiled the Australian urban renewal project Renew Newcastle. Sterling described the project as 'favela chic', a term he introduced earlier that month to describe a condition where 'you have no job, no money and no prospects, but you're wired to the gills and really hot on Facebook'. ${ }^{1}$ The word favela refers to large settlements, present in Brazilian cities, particularly Rio de Janeiro and São Paulo. Also known as shantytowns, squatter settlements, or slums; favelas are established without formal planning and government approval. ${ }^{2}$ Renew Newcastle fit the conceptual mould of 'favela chic' through its use of 'creepy, long-abandoned buildings', its installation of 'free wi-fi' and associated use of social media, and the populating of the abandoned district with 'artists and NGOs'. Sterling considers Renew Newcastle to possess the pre-eminent features of a 'post-scarcity' urban economy, where the favela's lack of 'formal infrastructure' and its 'makeshift property rights' is met with the creative and cultural production enabled by wireless internet.

With this bombastic metaphor, Sterling incises some key elements of a phenomenon that has come to be known as do-it-yourself (DIY) urbanism, loosely 
characterised as locally driven renovation, revamping and revivification of urban areas considered 'wasted', 'dead', or 'empty' by non-professional urban actors. ${ }^{3}$ DIY urbanism's projects particularly respond to the preponderance of empty buildings in urban areas. In its emerging and disuniting discourse, empty buildings are a symptom of urban decline and evidence of the flight of local capital, precipitated by the globalisation of trade and the recent global financial crisis. ${ }^{4}$ One of the movements exemplary projects, Renew Newcastle has a number of sister projects in other Australian cities, and there are related projects in place in the United Kingdom and the United States, such as Empty Shops, No Longer Empty; Meanwhile; Build a Better Block; and Lighter, Quicker, Cheaper. ${ }^{5} \mathrm{~A}$ key achievement in many cases is the coordination of temporary access to empty city buildings, usually zoned for retail or entertainment, for the purposes of housing 'creative, cultural and community projects'.6 This 'meanwhile use' of buildings for 'pop-up shops', art galleries, craft studios, charity drives, reading rooms and food co-operatives, among other 'ideas for empty space', is marked as providing 'renewal', 'rejuvenation' and 'revitalisation' to urban communities through the occupation and 'activation' of previously 'abandoned' parts of town. ${ }^{7}$

Projects that fall under the rubric of DIY urbanism have been examined in the context of a number of social, economic and conceptual trends, including the precarisation of creative, cultural and other immaterial labour; the relationship of creative and digital labour to the blurring of the lines between professional and amateur practice; the re-arrangement of cultural and creative production and consumption, the 'creative class' and 'creative city' theses of Richard Florida and Charles Landry and the critiques of these theses, particularly with regard to gentrification, subcultures and cultural capital; burgeoning analyses of local economies, local cultural production and local governance, particularly the decline of shopfront retail beyond shopping centres and strip malls; the process and politics of urban regeneration; and the paired phenomena of global cities and the globalisation of cities, particularly as regards city branding and indexes of 'liveability'.8

All these perspectives inform current scholarly analyses of DIY urbanism, but I have a more speculative aim in this essay. Here, I hope to discern a link between DIY urbanism and the demands of spatial justice; that is, the equitable distribution of 
places in which to live, be social and make culture. This link appears submerged, for example, in Sterling's conceptualisation of Renew Newcastle as 'favela chic'. The invocation of the favela might reference matters of spatial justice, in that the favela or slum is regularly taken as an inference of extreme urban poverty, and presents a globalised image of the impoverished and criminalised parts of Brazil's biggest cities. ${ }^{9}$ The favela may be cast up to urban planners or governments or concerned citizens as an image of their failure, signifying the lack of, and demand for, spatial justice: the 'City of God' in direct view of monied and securitised apartment blocks. ${ }^{10}$ The 'chic', however, suggests a beautification of these abjected urban spaces.11 The poor and criminal have been made pretty and fashionable-something that, as the scholarship and commentary on gentrification tells us, risks foreclosing the prospect of genuine spatial justice.12 Perhaps, then, DIY urbanism constitutes a partial or piecemeal claim to spatial justice, in that it uses the rhetoric of amateurism, marginality and informality to make space in the city-to occupy or build its 'favelas'. At the same time, it is a partial, or interested, claim; it cannot account for the marginality of others, and risks overriding it with an appropriative 'chic'.

\section{-AMATEUR CITY-MAKERS}

Implied in the term DIY urbanism is its anti-professional nature. Within this, notions of amateurism function as a cipher of marginality in the discourse of DIY urbanism, along with the trope of informality. Professionalism and formality are associated with the procedural complexity and monumentalism of large-scale urban developments. By contrast, DIY urbanism invokes the 'favela', the informal settlement, with the aesthetics of informality permeating the discourse through practices like Makeshift, Milkcrate Urbanism and Temporary Services (three collectives of artists, designers, architects and other urban practitioners). ${ }^{13}$ In the pursuit of 'chic', a border is struck between the amateurism, marginality and informality of DIY urbanism, and that of the favela-or more locally, the squat. That is, DIY urbanism's use of vacant buildings has a symbolic, if not also regulatory, relationship with the illegal occupation of property, or squatting, which may be associated with activist efforts to reclaim empty property as well as homelessness and 'sleeping rough'.14 The Australian renewal projects which are the focus of this essay have been referred to as 'a lawful version of [a] ... squat', and a professed 
benefit of the reactivating of disused building space in this manner is the protection against squatting it affords. ${ }^{15}$ According to Sydney's Empty Spaces, DIY urbanists make this protection available alongside the promise of various forms of capitalisation, such as 'growing the long term value of the property'. Not only can 'creative activity and creative vitality in an area ... push up property prices', but also legalised temporary occupants can take care of the property and guard against neglect. ${ }^{16}$ Occupants specifically prevent the 'vandalism and graffiti' as well as 'malicious damage' that empty buildings are prone to, along with squatting. ${ }^{17}$ In this sense, squatting and other 'neglectful' uses of urban space constitute a category of risk which renewal groups can mobilise to attract the interests of property owners, who may otherwise be averse to temporary occupation by an unknown and unpaying tenant. 18

For Renew Australia's Ianto Ware, the promise of valuable and/or productive occupation is a crucial pay-off for access to urban space. According to Ware, such space is often inaccessible due to the risk aversion of authorities. ${ }^{19}$ Projects such as Ware's and those associated with Renew Newcastle are especially interested in using these spaces because they are conducive to certain kinds of community and cultural development. As Ware's colleague Marcus Westbury has stated, temporary building use provides places to experiment, to fail and to prototype ideas and projects. This small-scale space is both necessary for the incubation of cultural products that may have high yield in the future, as well as having particular worth in the present-a condition Bruce Sterling refers to as 'permanent beta', or, the perpetually provisional nature of mentality and infrastructure that generates creative work. ${ }^{20}$ As a 'win-win' situation, the achievement of temporary building use for 'creative, cultural and community' projects also modifies the 'barriers to entry' that previously prevented people without high levels of financial capital from accessing space to host these projects. ${ }^{21}$ DIY urbanism's proponents position themselves against these barriers to entry. The North American practitioners of 'tactical urbanism', for example, write against urban planning regulations that frequently seem to serve 'interests disconnected' from the lives of ordinary citizens, and which operate 'at a scale for which they have little control'.22 DIY urbanists mark themselves as non-expert citizens smuggling themselves into a professionalised structure and making it work for them: 'hacking the city' from 'the bottom up'.23 
Already operating against the domination of government and finance capital, DIY urbanists also cite the barriers they face in regard to the programming and funding of state-sponsored art and culture-making. Empty Shops Network founder Dan Thompson writes of his artists' group 'struggling with no resources to stage artist-led festivals and open studio events', eventually founding the Empty Shops Network on 'no budget'.24 This 'struggle' is closely related to the impoverishment of individual practitioners. Westbury often refers to Renew's constituents as 'people without [the] capital' required to participate in dominant urban and cultural activity. ${ }^{25}$ In reference to his position as a critic of urban and cultural policy, Westbury has also nominated himself a 'cultural refugee', 'escaping' the state of New South Wales because of its poor cultural administration. ${ }^{26}$ DIY urbanism thereby functions as a retort to the domination of elite and large-scale forms of resourcing in this arena, along with an anti-professional approach to urbanism in general.

Amateurism, marginality and informality thus infuse the anti-professional and non-expert proponents of DIY urbanism, the experimental practices of the projects that occupy the spaces of DIY urbanism, and the practitioners themselves, as artists, culture-makers and/or cultural critics. To this end, proponents of the 'minor practice' of DIY urbanism cite their use of 'sweat equity' and voluntarism as well as the refusal of sanctioned 'experts'.27 These descriptors form the basis of their claims to empty or otherwise marginal urban space. At the same time, DIY urbanists also cite other forms of informality and marginality such as squatting, graffiti and vandalism in order to assert the professionally productive value of their claims to space.

\section{-DIY DISPLACEMENT?}

The shadow of squatting and dereliction lurking here demonstrates how such a temporary form of land use is problematic within cities, where property ownership is a key unit of organisation. ${ }^{28}$ As Westbury and others observe in their analysis of 'barriers to entry', the conditions for occupying, entering and using property are set by property owners, which includes private landlords and property groups, and government administration such as building codes and zoning regulations. ${ }^{29}$ For reasons that span property profitability and public health, these conditions are largely formed around the prevention of urban neglect and 'blight'. ${ }^{30}$ Hence, as I 
have claimed in commentary elsewhere, a question remains about the border between the amateurism, marginality and informality of DIY urbanists and their constituents, and that of other marginal and informal users of derelict or abandoned urban space, like graffitists, vandals and rough sleepers. This border is implied in the protection that DIY urbanism offers to property owners. ${ }^{31}$

There are well-established links between urban social exclusion and practitioners of squatting (as a feature of primary homelessness), graffiti and vandalism. ${ }^{32}$ Whether or not currently operational DIY urbanism schemes have displaced these other subjects of urban informality is currently unexplored in empirical studies of such projects themselves or of the changing uses of cities more generally. ${ }^{33}$ It is certainly the case, though, that some practitioners and allies of DIY urbanism express ambivalence or anxiety about spatial appropriation and urban displacement. For example, Chicago-based artist Jamie Keesling is uneasy with the artist-driven regeneration of Detroit (a city that has become iconic in the discourse of DIY urbanism), ${ }^{34}$ referring to 'socially motivated artists and activists, who ... are compelled to take advantage of inexpensive real estate' and the potential for this to see the 'gentrification of an entire city', a city that in the case of Detroit is affected by high levels of unemployment and poverty as well as long-standing racial inequality. Keesling wonders whether a distinction between 'the larger social context within which Detroit resides' and its 'immediate communities' of artists might be made more forcefully in order to avoid the complicity of DIY urbanism in urban displacement. ${ }^{35}$ New York's Aurash Khawarzad, who otherwise advocates for DIY urbanism in the United States, has also sounded concern about 'DIY displacement'. Khawarzad also notes the focus to date of many DIY projects on consumption via temporary or pop-up shops and laments the putative absence of a focus on 'creating equitable communities'. Khawarzad suggests the need for a 'post-hipster city' in the imagination of DIY urbanism, and makes an oblique reference to the role of taste in the discourse and design of DIY urbanist projects-invocating the hipster, a figure marked, like the bohemian of previous urban eras, by high levels of cultural, if not financial, capital. ${ }^{36}$ Indeed, beyond Khawarzad's misgivings, the hipster has been used to dismiss DIY urbanist projects entirely as 'hipster gentrification': the colonisation of urban space through cultural capital. ${ }^{37}$ As Bourdieu has shown, cultural capital enables the qualitative negotiation of power structures by those who 
possess it. Cultural capital is expressed in high levels of visual and textual literacy and often informed by a liberal arts education. This form of capital can thus be used to advocate and promulgate the lifestyles, habits and values of the people who carry it against those who possess these assets in lesser amounts. ${ }^{38}$

\section{-MEANWHILE AESTHETICS}

While an empirical study of cultural capital and DIY urbanism is yet to be conducted, it is notable that DIY urbanist projects have identifiable common aesthetics that are associated with the presumed subcultural proclivities of hipsters. Clothing and hand-crafted goods in a 'vintage' style, vinyl records, small bars and boutique coffee outlets are common to the cases analysed for this essay. ${ }^{39}$ Online consumption and distribution of cultural products is also paramount, as is the role of social media and niche websites in driving these projects forward. ${ }^{40}$ As Mark Greif and others have noted, these are the consumption habits of an urban middle class in possession of a thorough aesthetic education. They are also a class undergoing a widely felt renovation, with the retreat of structural features which might once have supported them, such as affordable housing, educational subsidies and reliable employment in the cultural sector ('no prospects, but wired to the gills', in Sterling's terms). ${ }^{41}$

Insofar as this recomposing class and its features constitute projects of DIY urbanism, it is notable that the scuttled subjectivity of the liberal-arts-educated middle class is also imbued with a particular temporality of the life course, and of everyday life. This temporality is implicated with the reconstitution of amateur practice. Amateur labour historically has operated outside the timeline of career progression; it was once less likely to signify a period 'before' professionalisation. However, in the age of the 'pro-am' and the precarious cultural worker, 'amateur' may refer more firmly to a period simultaneously 'in between' and 'before' full realisation. While wages for cultural labour have become more elusive at the same time as cities and professions have embraced a rhetoric of creativity, the 'pro-am' may be exploited for their immaterial labour as the precarious cultural worker undertakes yet another unpaid internship. ${ }^{42}$ The 'meanwhile' period associated with DIY urbanism's temporary building use, then, is evocative. ${ }^{43}$ Not only are many cultural producers experiencing the 'meanwhile' implicit in their continually deferred success, but the meanwhile begins 'after' dereliction, abandonment or 
emptiness, signifying some hope beyond financial crisis and straitened social mobility. 'Turning empty space into an opportunity', in the words of London's 3Space, speaks to the experience of physical as well as temporal emptiness. ${ }^{44}$ It may also be a reflection of the longing for like-minded society professed by many proponents-the 'cultural refugee' and the 'struggling artist' embracing space in the city for their community of interest to flourish. ${ }^{45}$ Amateurism, here, marks a temporal and affective experience that perhaps also accounts for the expression of informality and marginality in the discourse of DIY urbanism.

\section{-EXEMPLARY AMATEURISM}

With its particular amateurism, informality and marginality, the discourse of DIY urbanism encases claims to urban space along with promises to generate capital. This capital is associated with the aesthetics and tastes that might combat the undesirable and unproductive urban phenomena of squatting, vandalism, graffiti and dereliction. At the same time, DIY urbanists experience the 'poverty' of low financial capital and are obliged to justify their projects, at least in part, on the promise of returning capital to abjected urban space. Arguably, DIY urbanists demonstrate a claim to spatial justice against their financial poverty, but secure it through the use of cultural capital. This forecloses the possibility of spatial justice for users of abjected space who do not possess either form of capital. Therefore, the link between spatial justice and DIY urbanism is partial, both in terms of being piecemeal, and in being bound up with particular interests and privileges.

This partiality is especially visceral in the image of 'favela chic'. Sterling uses the favela to celebrate informal structures, 'bottom-up' in their development and autonomous from professional planning. He perhaps affirms the favela's ingenuity in the face of resource scarcity, in this sense. ${ }^{46}$ However, Sterling does not account at all for the entrenched impoverishment and marginalisation of favela residents, held in place by an extreme gap between rich and poor and with racialised origins in the global slave trade. ${ }^{47}$ As a metaphor for DIY urbanism, 'favela chic' elides these historical and material conditions of the favela's amateurism, informality and marginality, being concerned only with the applicability of the favela as a metaphor for emerging urban experience in Anglosphere cities. The incongruity between 'favela' and 'chic' is also innate to the enunciation of 'favela chic'; an incongruity 
which is echoed in the border between temporary use of buildings for 'creative, cultural and community' projects, and the 'squatting, vandalism, graffiti and dereliction' that such projects are held to guard against. Similarly, the amateurism emphasised in the discourse of DIY urbanism has its shadow in these abjected aspects of urban marginality. DIY urbanism's 'exemplary amateurism' demonstrates the limit points of its sanctioned claims to urban space, and points, at least, to the contestable and particular nature of these claims.

Ann Deslandes is a researcher, writer and community services worker in Sydney who works on the politics and ethics of solidarity. With Kristian Adamson she is the author of 'Zombie Solidarity', forthcoming in Andrew Whelan, Ruth Walker and Christopher Moore (eds), Zombies in the Academy: Living Death in Higher Education (2013). She has published other academic work in the Journal of Sociology, Australian Feminist Studies, Reconstruction and Cultural Studies Review.

\footnotetext{
-NOTES

${ }^{1}$ Bruce Sterling, 'Renew Newcastle', <http://www.wired.com/beyond_the_beyond/2009/07/renewnewcastle/>; 'Video from Reboot 11: Gothic High-tech and Favela chic', <http://www.wired.com/beyond_the_beyond/2009/07/ video-from-reboot-11/>.

2 Janice Perlman, Favela: Four Decades of Living on the Edge in Rio de Janeiro, Oxford University Press, New York, 2010, p. 29.

3 Mimi Zeiger, 'The Interventionist's Toolkit, Part 1', Places, The Design Observer Group,

$<$ http://places.designobserver.com/feature/the-interventionists-toolkit-part-1/24308/>. As Zeiger suggests, related terms include 'emergent urbanism', 'user-generated urbanism'. See also the Journal of Urbanism: International Research on Placemaking and Urban Sustainability, special issue on DIY urbanism, forthcoming. Marcus Westbury, 'DIY Transforming a Dying City',

<http://vimeo.com/15759471>; Wasted Spaces, <http://www.wastedspaces.org/about-this-site/>; Storefronts Seattle: Activating Empty Space with Art,

$<$ http://storefrontsseattle.wordpress.com/>; Marcus Westbury, 'Iterative Cities, or Why the Activity is More Important than the Act', <http://www.marcuswestbury.net/2012/12/05/iterative-cities-orwhy-the-activity-is-more-important-than-the-act/>.

4 Lauren Rosenberg, 'Art in Vacant Storefronts: A New Arena for Creative Research and Development', Masters thesis, Art Institute of Chicago, 2011, p. 4.

5 Dan Thompson, 'The Empty Shops Workbook', The Empty Shops Network and The Meanwhile Project, 2010, <http://www.artistsandmakers.com/staticpages/index.php/esnresources>; Mike Lydon (ed.), 'Build a Better Block', Tactical Urbanism, vol. 1, n.d.

$<$ http://issuu.com/streetplanscollaborative/docs/tactical_urbanism_vol.1>; 'Lighter, Quicker, Cheaper', <http://www.pps.org/lighter-quicker-cheaper/>.
} 
${ }^{6}$ Renew Newcastle, 'Propose a Project', <http://renewnewcastle.org/get-involved/propose-a-project>. 7 Emma Berwyn, 'In the Meanwhile: Can Urban Designers Utilise Meanwhile Use to Inform Future Uses?', MA Urban Design dissertation, University of Westminster, 2010,

$<$ http://www.meanwhilespace.com/news/can-urban-designers-utilise-meanwhile>; Dan Thompson, Pop Up People, Empty Shops Network, London, February 2012; Lauren Rosenberg, 'Art in Vacant Storefronts: A New Arena for Creative Research and Development', Masters thesis, Art Institute of Chicago, 2011, p. 4; Renew Australia, 'Matching Projects to Spaces',

<http://www.renewaustralia.org/diy-resources/matching-projects-to-spaces/>; Westbury, 'DIY Transforming a Dying City' and 'Renew Newcastle, Propose a Project'; Berwyn; Thompson, Pop Up People; Lydon et al.

8 For example, see Richard Florida, Cities and the Creative Class, Routledge, London, 2005; Charles Landry, The Art of City-making, Earthscan, Michigan, 2006; Charles Leadbeater and Paul Miller, The Proam Revolution, Demos, London, 2004; Sharon Zukin, Naked City: The Death and Life of Authentic Urban Places, Oxford, Oxford University Press, 2009; Jamie Peck, 'Struggling with the Creative Class', International Journal of Urban and Regional Research, vol. 29, no. 4, December 2005, pp. 740-70; Saskia Sassen, Cities in a World Economy, fourth edn, Sage, Los Angeles, 2012; Kirk Boyle and Daniel Mrozowski (eds), Bust Culture: The Great Recession in Fiction, Film, and Television, Lexington Books, forthcoming. Bust Culture: Notes from the Great Recession, <http://www.bustculture.com/>; Mark Banks, 'The Instrumental Leisure of the Creative Class', Working Paper no. 47, Centre for Research on Socio-Cultural Change, Open University, 2008; George Morgan and Xuefei Ren, 'The Creative Underclass: Culture, Subculture and Urban Renewal', Journal of Urban Affairs, vol. 34, no. 2, 2012, pp. 127-30.

9 Tucker Landesman, 'Remaking Rio: Favela Tourism and the Tourist Narrative', Favelissues, 22 February 2012, <http://favelissues.com/2012/02/22/remaking-rio-favela-tourism-and-the-touristnarrative-part-i/>.

${ }^{10}$ Antônio Augusto Veríssimo, 'Housing, Employment and Mobility: The Debate on the Location of Social Interest Housing in Rio de Janeiro', trans. Sarah de Rose, RioOnWatch, 12 July 2012,

$<$ http://rioonwatch.org/?p=4313>; Ananya Roy, 'Slumdog Cities: Rethinking Subaltern Urbanism', International Journal of Urban and Regional Research, vol. 35, 2011, pp. 223-38.

11 One commentator on Renew Newcastle applauded the scheme on particularly visual and geopolitical terms, considering 'Newcastle's resemblance to Baghdad over the years'. Skynoise, Renew Newcastle, <http://www.skynoise.net/2009/07/09/renewing-newcastle/>.

12 See for example, Zukin; Morgan and Ren.

13 The right to the city symposium,'Milkcrate Urbanism', April 2011.

<http://www.therighttothecity.com/exhibitionmilkcrate.html>; 'Makeshift', $<$ http://www.therighttothecity.com/exhibitionmakeshift.html>; Temporary Services, 'In Public', $<$ http://www.temporaryservices.org/in_public_index.html>.

${ }^{14}$ Nicholas K. Bromley, Unsettling the City: Urban Land and the Politics of Property, Routledge, New York and London, 2004, p. 20.

15 University of Technology Newsroom, 'Restore, Renew, Regenerate', 7 May 2012,

$<$ http://newsroom.uts.edu.au/news/2012/05/renew-restore-regenerate>.

16 Empty Spaces, 'Landlords and Empty Spaces',

<http://emptyspaces.culturemap.org.au/page/landlords>

17 Empty Spaces, 'A Landlord's Story', <http://emptyspaces.culturemap.org.au/page/gpt>; see also

3Space, 'Regeneration' <http://3space.org/resources/regeneration>.

18 Empty Spaces, 'A Landlord's Story'. 
${ }^{19}$ See, for example, Ianto Ware, 'Making Things Happen: Reflections on the User Generated Cities Forum', <http://driantoware.wordpress.com/2011/04/27/making-things-happen-reflections-on-theuser-generated-cities-forum>.

${ }^{20}$ Marcus Westbury, 'Cities as Software', Volume, no. 27, 2011, pp. 89-92; Sterling.

${ }^{21}$ Renew Newcastle, 'The Can Do Guy', <http://renewnewcastle.org/media/post/the-can-do-guy/>;

'Renew Australia', Media, Renew Australia, <www.renewaustralia.org/2011/10/renew-australia/>.

22 Lydon, ed.

23 'Hack Your City', <http://www.hackyourcity.com>; 'DIY Urbanism: City Building from the Bottom Up', <http://yuriartibise.com/blog/diy-urbansim/>

${ }^{24}$ Dan Thompson, 'The Empty Shops Network: A Big Thankyou',

$<$ http://mrdanthompson.wordpress.com/2010/02/25/the-empty-shops-network-a-big-thank-you/>. 25 Westbury, 'Cities as Software'.

${ }^{26}$ Marcus Westbury, 'In Praise of Initiative, or, Why Bob Carr Made Me Move to Melbourne', blogpost, 12 October 2010, <http://www.marcuswestbury.net/2010/12/10/in-praise-of-initiative-or-why-bobcarr-made-me-move-to-melbourne/>.

27 The Right to the City exhibition and publishing project, Sydney, 2011, call for papers, $<$ http://www.therighttothecity.com/symposiumprogram.html>; Street Sense, 'DIY Urbanism', $<$ http://www.street-sense.org/streettalk/2011/2/13/diy-urbanism.html>; Empty Shops Network and The Meanwhile Project, The Empty Shops Workbook,

<http://www.artistsandmakers.com/staticpages/index.php/esnresources>; Ianto Ware, 'Picking Fights in Preparation for the Festival of Unpopular Culture', The Blog Formerly Known as the Renew Adelaide Blog, 4 October 2011, <http://renewadelaide.wordpress.com/2011/10/04/picking-fights-inpreparation-for-the-festival-of-unpopular-culture/>.

28 Edward W. Soja, Seeking Spatial Justice, University of Minnesota Press, Minneapolis. p. 32.

29 'Renew Australia', Media release.

30 John Ratcliffe, Michael Stubbs and Miles Keeping, Urban Planning and Real Estate Development, third edn, Routledge, Oxon \& New York, 2009.

${ }^{31}$ Ann Deslandes, 'What Do Pop-up shops and Homelessness have in Common?', The Global Urbanist, 14 February 2012, <http://globalurbanist.com/2012/02/14/diy-urbanism-homelessness>.

32 Francisco Azpitarte, Social Exclusion Monitor Bulletin, Brotherhood of St Laurence and Melbourne Institute of Applied Economic and Social Research, April 2012; Rowland Atkinson and Keith Jacobs, Public Housing in Australia: Stigma, Home and Opportunity, Housing and Community Research Unit, School of Sociology and Social Work, University of Tasmania, Paper no. 01, 2008; Catherine Robinson, 'Persistent Homelessness/Persistent Trauma', Parity, vol. 18, no. 7, 2005, pp. 4-5.

33 Rowland Atkinson and Hazel Easthope, 'The Consequences of the Creative Class: The Pursuit of Creativity Strategies in Australia's Cities', International Journal of Urban and Regional Research, vol. 33 no. 1, 2011, pp. 64-79.

${ }^{34}$ Renew Australia's Ianto Ware, for example, refers to a series of abandoned buildings in Adelaide as 'Adelaide's Little Detroit', 'Why Someone Should Just Give Tuxedo Cat a Heap of Cash', The Blog Formerly Known as the Renew Adelaide Blog, 20 January 2011,

$<$ http://renewadelaide.wordpress.com/2011/01/20/why-someone-should-just-give-tuxedo-cat-aheap-of-cash>.

35 Jamie Keesling, 'Pioneering Detroit: Utopic Visions for a Post-industrial Landscape', Chicago Art Magazine, 2010, <http://chicagoartmagazine.com/2010/11/pioneering-detroit-utopic-visions-for-apost-industrial-landscape/>.

36 Tida Tippapart, 'Creating the Post-hipster City: In Conversation with Aurash Khawarzad', Huffington Post, 22 May 2012, <http://www.huffingtonpost.com/tida-tippapart/new-york-art-hipsters-brooklyn- 
_b_1537126.html>; Mark Greif, Kathleen Ross and Dayna Tortorici (eds), What was the Hipster? A Sociological Investigation, n+1 Foundation, New York, 2012.

37 Mattilda Berstein Sycamore, 'Is DIY Business Still Gentrification?', May 2006,

<http://mattildabernsteinsycamore.com/maximum_may2006.html>.

${ }^{38}$ David Ley, 'Artists, Aestheticisation and the Field of Gentrification', Urban Studies, vol. 40, no. 12, November 2003, pp. 25, 27-44.

${ }^{39}$ See for example: 'Pop into Pop-up Shop and Pop-on Vintage Clothes!', Buckingham Today, 24

November 2011, <http://www.buckinghamtoday.co.uk/lifestyle/local-

entertainment/pop_into_pop_up_shop_and_pop_on_vintage_clothes_1_3274207>; 'LittlestVINTAGE, All

Grown Up!', Renew Adelaide, <http://www.renewadelaide.com.au/2012/03/30/littlestvintage-all-

grown-up/>; 'The Terrace Bar', Renew Newcastle,

$<$ http://renewnewcastle.org/projects/about/project/the-terrace-bar/>; 'Cleveland's Better Block

Inspired Pop-up Pearl Announced for May 19', Build a Better Block, <http://betterblock.org/?p=745>.

40 Westbury, 'Cities as Software'.

41 Greif, Ross and Tortorici (eds); Melissa Gregg, Work's Intimacy, Polity, London, 2011.

42 David Hesmondhalgh and Sarah Baker, '"A Very Complicated Version of Freedom": Conditions and

Experiences of Creative Labour in Three Cultural Industries', Poetics, vol. 38, pp. 4-20, 2010.

43 See also Melissa Gregg on the 'state of exception' that characterises much contemporary creative or cultural labour in her 'Labour Politics and the State of Exception', plenary presentation at the Moral Economies of Creative Labour conference, University of Leeds, July 2011.

44 3space, <http://3space.org>.

45 See, for example, Julia Lenton (ed.), 1,386 Days at FraserStudios, Queen Street Studio, Sydney, 2012, pp. $19,42,44,61,68,69$.

46 Catalytic Communities, 'The Favela as a Sustainable Model',

$<$ http://www.catcomm.org/en/?p=5291>.

47 Perlman; Lourdes Carril, Quilombo, favela e periferia: A longa busca da cidadania, Annablume, Sao Paulo, 2006. 